\title{
Micropropagation and experimental field cultivation of Pulsatilla turczaninovii Kryl. et Serg. (Ranunculaceae)
}

\author{
Ewa Hanus-Fajerska ${ }^{1}$ (1) Dawid Kocot ${ }^{2} \cdot$ Alina Wiszniewska $^{1} \cdot$ Aleksandra Koźmińska $^{1} \cdot$ Ewa Muszyńska $^{3}$
}

Received: 12 March 2021 / Accepted: 2 July 2021 / Published online: 15 July 2021

(c) The Author(s) 2021

\begin{abstract}
Pulsatilla turczaninovii is an important medicinal plant, valued for high ornamental value of melliferous flowers. We assessed the efficiency of reproduction under in vitro conditions and the ex situ growth capacity of this important representative of the world flora. The seed germination percentage was assessed, followed by determination of micropropagation rate and rooting efficiency. Then, the possibility of plant development in three consecutive growing seasons was assessed. The in vitro germination percentage was approximately 55\%. The highest multiplication coefficient, amounting to 5.17, was obtained on modified MS medium supplemented with $2.5 \mathrm{mg} \mathrm{L}^{-1} 2 \mathrm{iP}$ and $1.0 \mathrm{mg} \mathrm{L}^{-1}$ IAA. Our study provided unique insight on biochemical background of root regeneration in P. turczaninovii. In comparison with standard auxin-supplemented rooting medium, the treatment with $1.0 \mathrm{mg} \mathrm{L}^{-1}$ level of ethylene precursor ACC elevated rooting by about $20 \%$. The total content of soluble sugars was proved to be biomarker of rhizogenesis in the studied species. Their concentration was positively correlated with rooting efficiency, while a level of phenolic was positively correlated with the length of regenerated roots, and their number per rosette. The cultivation of the acclimatized material was successfully carried out and was evaluated over three subsequent years. In the third year of cultivation, the plants entered the stage of generative development and most of them bloomed profusely.
\end{abstract}

\section{Key message}

The protocol of Pulsatilla turczninowi propagation, rooting, hardening and ex situcultivation was developed. Biochemical background of adventitious rooting process in a representative of Pulsatilla genus is reported for the first time.

Keywords Vegetative multiplication · Adventitious roots $\cdot$ Rooting biomarkers · Siberian pasque flower $\cdot$ Ex situ collection

\section{Abbreviations \\ ACC 1-Aminocyclopropane-1-carboxylic acid \\ IAA Indole-3-acetic acid \\ IBA Indole-3-butyric acid}

Communicated by M. I. Beruto.

Ewa Hanus-Fajerska

e.hanus-fajerska@urk.edu.pl

1 Department of Botany, Physiology and Plant Protection, Faculty of Biotechnology and Horticulture, University of Agriculture in Kraków, Al. 29 Listopada 54, 31-425 Kraków, Poland

2 University of Agriculture in Kraków, Al. Mickiewicza 21, 31-120 Kraków, Poland

3 Department of Botany, Institute of Biology, Warsaw, University of Life Sciences-SGGW, Nowoursynowska 159, Building 37, 02-776 Warsaw, Poland
MS Murashige and Skoog medium

POD Peroxidase (EC 1.11.1.7)

TPC Total phenolic compounds

TSS Total soluble sugars

WPM Woody Plant Medium

\section{Introduction}

Pasque flowers (Pulsatilla spp., Ranunculaceae) are not only important components in natural ecosystems (Bochenková et al. 2012, 2015) but are also widely exploited by human. Numerous species have medicinal properties (Danova et al. 2009; Hao et al. 2015; Lin et al. 2011; Łaska et al. 2019; Łaska and Sienkiewicz 2019), whereas ornamental, honey-yielding cultivars are readily cultivated in gardens (Weryszko-Chmielewska et al. 2017). Horticultural exploitation of Pulsatilla species is constantly extending, and novel 
studies concerning kariotyping and molecular analyses of nuclear and cytoplasmatic genetic material facilitate their introduction into breeding programs (Mlinarec et al. 2016; Sramkó et al. 2019). A melliferous species Pulsatilla turczaninovii from subsection Albanae, native to Asian forest and alpine meadow steppes (Ermakow et al. 2014), may be a prospective and valuable plant material for cultivation in green areas.

Siberian pasque flower is a perennial that grows in different habitats on a fairly poor soil, such as subalpine or alpine natural grasslands steppes, xerothermic grasslands or so called meadow steppes. All these habitats are currently being degraded, and, frequently their constant fragmentation is taking place (Di Musciano et al. 2018; Ermakow et al. 2014). Pulsatilla specimens are found mainly in vegetationfree gaps on grasslands, as this hemicryptophyte prefers illuminated locations (Zainelabdeen et al. 2020). Since such microhabitats may be quickly covered with high vegetation or moss layers (Gantuya et al. 2019; Xu et al. 2020) this species is endangered in the natural environment. Another P. turczaninovii habitat, lake Baikal's region, is becoming an unstable area due to anthropogenic activities (Popovicheva et al. 2021). Thus the introduction of this species into in vitro culture, as a means of achieving efficient plant reproduction, is justified from a conservation perspective and from a horticultural practice.

Micropropagation techniques enable faster production of vegetative offspring in comparison with classic reproduction methods (Hanus-Fajerska et al. 2019; Muszyńska et al. 2018; Philips and Garda 2019). Culturing tissues and organs in vitro allows regenerating numerous micro-plantlets, from single donor plant or from its fragments. To date a few important contributions presenting in vitro culture protocols of some European (Priede and Kḷaviņa 2011) and Asiatic (Jin et al. 2007; Lin et al. 2011) Pulsatilla species have been published. The study of Priede and Kḷavina (2011) revealed that these plants are difficult-to-root, and usually multi-step protocol is required for root development. Rooting difficulties may be related to fluctuations and impairments in the contents and activity of some biochemical parameters that could be considered as markers of rhizogenesis. These may include the content of phenolic compounds, carbohydrates and the activity of antioxidant enzymes, which would change during successive stages of rooting (Denaxa et al. 2012, 2020). Treatment with plant growth regulators, especially with exogenous auxins, is crucial for the development of adventitious roots (Priede and Kḷavina 2011; Park et al. 2017). Rooting is also affected by ethylene fluctuations, however whether the effect is stimulatory or inhibitory depends on the species and other physicochemical stimuli (Xu et al. 2017; Fattorini et al. 2018). To our knowledge, biochemical background of rooting in representatives of Pulsatilla genus still remains unclear.
We have thus undertaken the comprehensive study on Pulsatilla turczaninovii with the aim of elaborating the successive steps of in vitro propagation system, involving culture initiation, micro-rosettes multiplication, and their rooting to obtain regenerated plants. We tested formation of roots under auxin and ethylene precursor (1-aminocyclopropane-1-carboxylic acid (ACC)) treatments, applied alone or in combination with auxins. Additionally, to make an insight into the rooting process we correlated determined rooting parameters with fluctuations in the level of phenolic compounds, total soluble sugars and POD activity. We also assessed the growth of the obtained $P$. turczaninovii plants during their cultivation in the Polish climatic conditions with the intention of creating an ex situ collection in the future, which could partially contribute to the Pulsatilla protection program.

\section{Materials and methods}

\section{The seeding material}

In the present study the research material was Pulsatilla turczaninovii Kryl. et Serg. (Ranunculaceae). The initial material (i.e. fruits) was collected from a natural population growing in Siberia at a site located in Sludian Region in the Irkutsk Oblast, Russia with the geographical coordinates 51.7 N, 103.7 E. Population from which fruit samples were obtained grew on the grassy shores in the region of Lake Baikal, located inside the Eurasian continent (Suppl. Fig. 1). The formal verification of plant material was conducted by Mrs. Anna Pacyna Ph.D. from W. Szafer Institute of Botany, Polish Academy of Sciences, Kraków, Poland, for which we are grateful. About 300 maturing achenes were collected by hand in mid-July 2012 . Seed cleaning was performed at the site, by hand removal of small distorted fruits and stem debris or tiny leaf fragments. After this pre-screening, the purified samples were stored in paper envelopes at $20^{\circ} \mathrm{C}$. Elongated pistil styles were manually removed from achenes prior to seeding.

\section{Initiation of in vitro culture}

The germination in the seed boxes of $P$. turczaninovii seeding material was preliminarily evaluated. Then fruits were surface sterilized by immersion in $70 \%$ ethanol for $2 \mathrm{~min}$, followed by immersion for $4 \mathrm{~min}$. in $0.1 \%(\mathrm{w} / \mathrm{v})$ mercuric chloride $\left(\mathrm{HgCl}_{2}\right)$ solution containing 3 drops of Tween80 , and then thoroughly rinsed four times with autoclaved distilled water. Aseptic achenes were placed on medium, described as step zero S0, containing $1 / 4$ concentration of MS salts (Murashige and Skoog 1962) deprived of phytohormones but supplemented with $0.1 \mathrm{~g} \mathrm{~L}^{-1}$ myo-inositol, 
$0.5 \mathrm{mg} \mathrm{L}^{-1}$ tiamine, $0.5 \mathrm{mg} \mathrm{L}^{-1}$ pyridoxine, $0.5 \mathrm{mg} \mathrm{L}^{-1}$ nicotinic acid, as well as $20 \mathrm{~g} \mathrm{~L}^{-1}$ sucrose, $0.6 \mathrm{~g} \mathrm{~L}^{-1}$ activated charcoal, and $5.0 \mathrm{~g} \mathrm{~L}^{-1}$ agar (Difco Laboratories Inc. UK). The germination percent in vitro on 1/4 MS medium was also checked. Achenes with gentle incised pericarp were placed in $100 \mathrm{~mL}$ Erlenmeyer flasks filled with $10 \mathrm{~mL}$ of medium. The single experiment consisted of 10 flasks with 10 achenes per flasks, and was repeated twice. Germination was carried out in a growth chamber illuminated with white light during the day, using of $16 / 8$ photoperiod and a temperature of $22 / 14{ }^{\circ} \mathrm{C}$ (day/night). After four weeks the number of aseptic seedlings obtained under in vitro conditions was assessed.

\section{In vitro vegetative step-plant material and culture conditions}

Fragments from aseptic seedlings were used as a primary explants for the establishment of tissue culture. Their apical parts, 15-20 mm long, were placed vertically on the medium. For the propagation experiment the explants were taken from stabilized culture i.e. one that was previously conducted during two passages, which showed stable growth parameters. During this step two types of media were tested, MS (Murashige and Skoog 1962) and Woody Plant Medium (WPM) (Lloyd and McCown 1980), both supplemented with $2.0 \mathrm{mg} \mathrm{L}^{-1}$ glycine, $0.1 \mathrm{mg} \mathrm{L}^{-1}$ tiamine, $0.5 \mathrm{mg} \mathrm{L}^{-1}$ pyridoxine, $0.5 \mathrm{mg} \mathrm{L}^{-1}$ nicotinic acid, $0.1 \mathrm{~g} \mathrm{~L}^{-1}$ myo-inositol, $20 \mathrm{~g}$ $\mathrm{L}^{-1}$ sucrose, $0.5 \mathrm{~g} \mathrm{~L}^{-1} \mathrm{PVP}, 0.65 \mathrm{~g} \mathrm{~L}^{-1}$ calcium gluconate.

Such experiment was divided into two stages, the first (S1) and second (S2), which lasted 4 and 6 weeks, respectively. The first passage was slightly shorter, so that the culture was enriched with fresh nutrients relatively quickly. Media in the two stages differed in relation to plant growth regulators concentration. In $\mathbf{S} 1$ two media were tested: S1-1: $\mathrm{MS}+0.5 \mathrm{mg} \mathrm{L}^{-1} \mathrm{~N} 6$-[2-isopentyl]adenine (2iP), $0.1 \mathrm{mg} \mathrm{L}^{-1}$ indole-3-acetic acid (IAA); and S1-2: $\mathrm{WPM}+2.5 \mathrm{mg} \mathrm{L}^{-1} 2 \mathrm{iP}$ and $1 \mathrm{mg} \mathrm{L}^{-1} 1$-naphthaleneacetic acid (NAA). In the second step $\mathbf{S 2}$ four media formulations were evaluated: $\mathbf{S 2 - 1}: \mathrm{MS}+1.0 \mathrm{mg} \mathrm{L}^{-1} 2 \mathrm{iP}+0.2 \mathrm{mg}$ $\mathrm{L}^{-1}$ IAA; S2-2: $\mathrm{WPM}+1.0 \mathrm{mg} \mathrm{L}^{-1} 2 \mathrm{iP}+0.2 \mathrm{mg} \mathrm{L}^{-1}$ IAA; S2-3: $\mathrm{MS}+2.5 \mathrm{mg} \mathrm{L}^{-1} 2 \mathrm{iP}+1 \mathrm{mg} \mathrm{L}^{-1}$ IAA; S2-4: $\mathrm{WPM}+2.5 \mathrm{mg} \mathrm{L}^{-1} 2 \mathrm{iP}+1 \mathrm{mg} \mathrm{L}^{-1}$ IAA. Medium $\mathrm{pH}$ was adjusted to 5.8 prior to solidification with $8.0 \mathrm{~g} \mathrm{~L}^{-1}$ agar and autoclaving for $20 \mathrm{~min}$ at $0.1 \mathrm{MPa}$. Explants were cultured in $250 \mathrm{~mL}$ Erlenmeyer flasks containing $50 \mathrm{~mL}$ of the respective medium, using at least four explants for flask. The cultures were kept in a vegetation chamber with $70 \%$ air humidity, $22{ }^{\circ} \mathrm{C}$ day $/ 18{ }^{\circ} \mathrm{C}$ night temperature, with a $16 / 8 \mathrm{~h}$ photoperiod. The light source was cool white fluorescent lamps with a photon flux density of $80 \mu \mathrm{mol} \mathrm{m} \mathrm{m}^{-2} \mathrm{~s}^{-1}$ at the level of cultured material. The experiment was carried out in six replications, and it was repeated twice. Biometric measurements of explants were carried out. After measuring the fresh weight $(\mathrm{FW})$, a part of the fresh material was dried in the oven for $24 \mathrm{~h}$ at $105^{\circ} \mathrm{C}$, until constant weight in order to obtain dry weight (DW). FW and DW data were then used to calculate the water content percentage. Multiplication coefficient (MC) was calculated as the number of newly formed rosettes from one initial explant. The length of micro-rosettes was measured as well as the number of leaves per single rosette was counted.

\section{The rooting step and determination of the rooting stage markers}

The starting material for the rooting step was $P$. turczaninovii line from the in vitro vegetative propagation stage which turned out to be favorable propagation medium. It was cultivated on modified S1-1 medium (MS + $0.5 \mathrm{mg}$ $\mathrm{L}^{-1} 2 \mathrm{iP}, 0.1 \mathrm{mg} \mathrm{L}^{-1} \mathrm{IAA}$ ); followed by $\mathrm{S} 2-1$ (MS $+1.0 \mathrm{mg}$ $\mathrm{L}^{-1} 2 \mathrm{iP}+0.2 \mathrm{mg} \mathrm{L}^{-1} \mathrm{IAA}$ ). The plant material was cut to approx. 20-mm long explants (micro-rosettes), which were transferred to rooting induction media described as S3: i.e. S3-1: MS medium without phytohormones (control treatment), S3-2: $\mathrm{MS}+1.0 \mathrm{mg} \mathrm{L}^{-1}$ indole-3-butyric acid (IBA); S3-3: $\mathrm{MS}+1.0 \mathrm{mg} \mathrm{L}^{-1}$ ACC (treated as supercontrol); and S3-4: $\mathrm{MS}+1.0 \mathrm{mg} \mathrm{L}^{-1} \mathrm{IBA}+1.0 \mathrm{mg} \mathrm{L}^{-1}$ ACC. For each treatment (for each medium variant) fifteen culture flasks, with three rosettes each, were prepared. The induction phase took 7 days, and afterwards microplants were transferred to a hormone-free medium (S3-1) for 6 weeks for root elongation. Regenerated roots were counted and measured for each individual micro-rosette, the rooting efficiency was assessed on the basis of percentage of rooted plantlets. Data were collected from 45 plantlets from each medium variant.

\section{Biochemical analyses}

Biochemical analyses (TPC, TSS and POD) were conducted (in micro-rosettes) at the beginning of rooting induction phase (day 0 , here referred to as a control) and at $2^{\text {nd }}$ and $7^{\text {th }}$ day of rooting induction phase.

\section{Total phenolic compounds (TPC)}

The content of total phenolic compounds was determined in $80 \%(\mathrm{v} / \mathrm{v})$ methanol extract of $100 \mathrm{mg}$ of fresh plant material and quantified as described in Blainski et al (2013) by a reaction with the Folin-Ciocalteu reagent. The extracts were mixed with the reagent and sodium carbonate and left in the dark for $90 \mathrm{~min}$. Absorbance was recorded at $765 \mathrm{~nm}$, and the results were expressed in equivalents of gallic acid used as a standard ( $\mathrm{mg}$ eq $\mathrm{GA} \mathrm{g}^{-1} \mathrm{FW}$ ). 
Total soluble sugars (TSS)

The soluble sugars content was quantified according to the method described by Powel (1973). $100 \mathrm{mg}$ of fresh material was mixed with $80 \%$ methanol on orbital shaker overnight, $100 \mu \mathrm{L}$ of the extracts was mixed with $0.5 \mathrm{~mL}$ of $5 \%$ phenol and $2.5 \mathrm{~mL}$ of concentrated sulfuric acid before absorbance reading were taken at $490 \mathrm{~nm}$. TSS contents were expressed as mg equivalent of glucose per gram FW.

\section{Peroxidase (POD) activity}

POD activity was measured according to the method described by Putter (1974) with minor modifications. $100 \mathrm{mg}$ of plant material was homogenized in $5 \mathrm{~mL}$ icecold phosphate buffer ( $\mathrm{pH}$ 6.2). The extracts were centrifuged at $4{ }^{\circ} \mathrm{C}$ for $15 \mathrm{~min}$. at $4800 \mathrm{~g}$ and the supernatants were analyzed. For analyses of POD activity $p$-phenyldiamine was used as enzyme substrate, which is oxidized by POD to phenazine. $1 \mathrm{~mL}$ of extract was mixed with $0.1 \mathrm{~mL}$ of phosphate buffer. $0.1 \mathrm{~mL}$ of $1 \%$ solution of p-phenyldiamine was mixed with $0.1 \mathrm{~mL}$ of $0.1 \% \mathrm{H}_{2} \mathrm{O}_{2}$. The absorbance of colored reaction product was measured at $485 \mathrm{~nm}$. One unit of POD activity corresponds to an absorbance increase of 0.1 .

\section{Plant cultivation}

The 50 microplants were planted in pots $(30 \mathrm{~mm}$ in diameter) containing the mixed medium i.e. peat, sand and perlite (1:1:1). After a five-week of preliminary acclimatization to ex vitro growing conditions they were planted to the ground in the rock garden, located in Pyrzowice (south Poland, $50.5 \mathrm{~N}, 19.1 \mathrm{E}$ ). The material used to build the rock garden was limestone and sandstone. The garden was located in the frost resistance zone $6 \mathrm{~b}$, which means that the average below-zero temperature in winter ranged from -20.5 to $-17.8{ }^{\circ} \mathrm{C}$, and during the vegetation period from 15 to $35^{\circ} \mathrm{C}$. The average annual rainfall is $600-700 \mathrm{~mm} /$ year. The development of regenerated plants, obtained as a result of micropropagation, was monitored during two consecutive periods of vegetation while being compared to reference plant material obtained directly from sowing. In order to obtain the reference plant material randomly selected 35 achenes. were sown at a constant density, one for each square centimeter in a substrate consisting of peat, sand and perlite (1:1:1). The germination percentage was assessed after 4 weeks. Obtained plants were transplanted into pots and cultivated to maturity. In the second year, after overwintering, the plants were transferred from pots to be cultivated in the ground.

\section{Statistical analysis}

Experiments were organized according to a randomized design. In the methodology, the exact number of repetitions is given for each stage of in vitro experiments. During biochemical analyses the mean and standard deviation ware calculated from five replicates per medium for each set day. Shapiro-Wilk test was used to check for normality assumption. The results were subjected to a statistical analysis using the ANOVA module in STATISTICA ver. 13.0 software (StatSoft Inc.). A post-hoc comparisons were made with Tukey test, and the differences between means were assessed at $\mathrm{P}<0.05$. Rooting parameters and the content of biochemical markers (TPC, TSS, POD activity) were correlated using correlation matrix module. Correlation coefficients $<-0.7$ and $>0.7$ were considered significant.

\section{Results}

\section{Culture initiation, in vitro vegetative propagation and rooting of micro-rosettes}

Seed germination on 1/4 MS medium under in vitro conditions was satisfactory, as $54.8 \%$ of them germinated on culture medium, despite the drastic treatment for surface decontamination. A similar percentage (49.7\%) was obtained for seeds sown directly into the substrate in order to obtain the reference plants which were assumed to be a model for plants from micropropagation. The appearance of the microrosettes is shown in Fig. 1A. During propagation experiment, some rosettes regenerated on the modified WPM medium (S1-2) were in poor condition, with anthocyanin coloration, and some of them dried up over time (Fig. 1B). In turn, the rosettes obtained on the MS (S1-2) were properly colored, multiplied well and had healthy appearance (Fig. 1C). The average FW of shoots obtained on the modified S1-1 medium (0.48 g), and was about twice as high as FW of shoots obtained on S1-2 medium (Table 1). Likewise, the average DW of rosettes was higher for the cultures grown on MS medium and amounted to $0.063 \mathrm{~g}$. The multiplication coefficient of the cultures on the S1-1 medium was higher, and reached 5.24, compared to the S1-2 medium (1.0) (Table 1). The average number of regenerated rosettes did not change significantly with successive passages, only new leaves emerged. On the S1-2 medium, the plant material did not multiply as effectively as on S1-1 throughout the experiment.

During the second stage of micropropagation, media were diversified in a relation to phytohormone concentration. The shoots multiplied on all tested media, but the best effects were observed on S1/S2-3 where multiplication coefficient amounted to 5.17 (Table 1). On media S2-3 and 
S2-4 rosettes achieved the highest FW (Table 1). No statistical differences were observed regarding DW of plantlets developed. The longest leaves grew on S2-4 medium. On the medium S2-3, micro-rosettes produced the highest number of green leaves, which averaged to 23.17. The highest number of leaf with necrosis symptoms was recorded on S2-4, amounting to 10.5 , and exceeding the number of green leaves developed on the rosettes (2.83).

During 8 weeks of rooting phase, rosettes regenerated roots more efficiently on the tested media S3-2, S3-3 and S3-4, in comparison with S3-1 medium (Table 2). The highest rooting efficiency was noted on media S3-3 and
S3-4, supplemented with ACC and it was 19.9 and $15.5 \%$, respectively (Fig. 1D, Table 2). Irrespectively of the rooting medium, the average number and average length of adventitious roots was similar (Table 2).

\section{Changes in biochemical parameters during rooting induction phase}

The initial concentration of total phenolic compounds (TPC), determined at the beginning of rooting induction phase (day 0 ) on each rooting medium was the same (Fig. 2A). On control medium S3-1 the amounts of TPC did
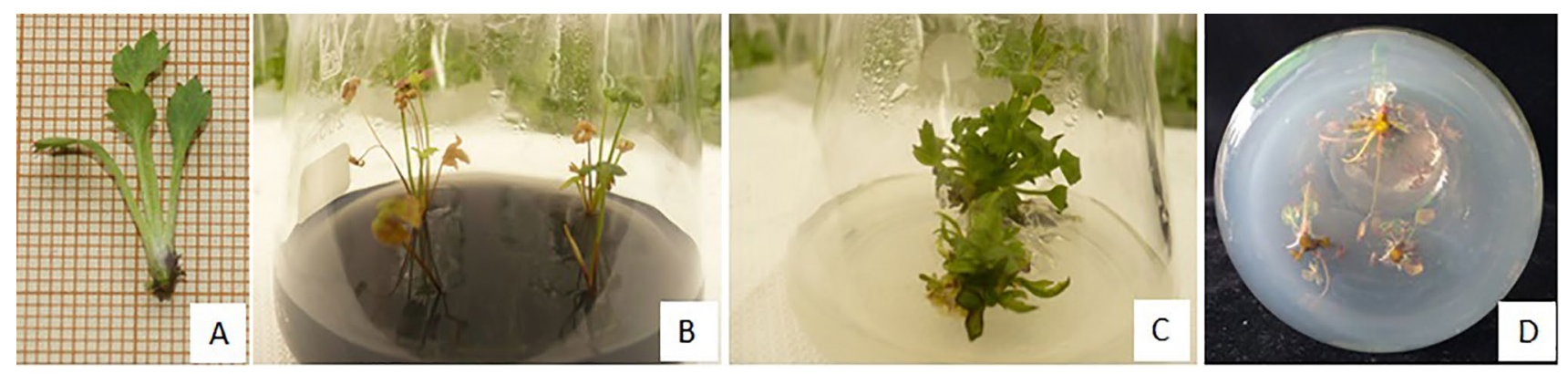

Fig. 1 Development of shoot culture and rooting of micro-rosettes. A Initial explant, microshoot, B micro-rossetes on WPM medium, C microrossetes on MS medium, $\mathbf{D}$ micro-rossetes during in vitro rooting

Table 1 Growth parameters and propagation efficiency of Pulsatilla turczaninovii micro-rosettes assessed 4 weeks (S1-1, S1-2) and 6 weeks (S2-1, S2-2, S2-3, S2-4) from the last passage of the culture

\begin{tabular}{|c|c|c|c|c|c|c|c|}
\hline & & \multicolumn{6}{|l|}{ Medium } \\
\hline & & S1-1 & S1-2 & S2-1 & S2-2 & S2-3 & S2-4 \\
\hline \multicolumn{2}{|l|}{ FW of rosettes [g] } & $0.482 \pm 0.18 b$ & $0.254 \pm 0.10 \mathrm{ab}$ & $0.269 \pm 0.12 \mathrm{ab}$ & $0.167 \pm 0.06 \mathrm{a}$ & $0.619 \pm 0.34 \mathrm{c}$ & $0.561 \pm 0.19 b c$ \\
\hline \multicolumn{2}{|l|}{ DW of rosettes $[\mathrm{g}]$} & $0.063 \pm 0.02 b$ & $0.043 \pm 0.02 \mathrm{a}$ & $0.95 \pm 0.03 \mathrm{c}$ & $0.115 \pm 0.08 \mathrm{c}$ & $0.144 \pm 0.14 \mathrm{c}$ & $0.105 \pm 0.03 \mathrm{c}$ \\
\hline \multicolumn{2}{|l|}{ WC\% of rosettes } & $87.03 \pm 2.77 b$ & $83.75 \pm 3.55 b$ & $63.01 \pm 4.92 \mathrm{a}$ & $61.63 \pm 3.18 \mathrm{a}$ & $75.67 \pm 3.74 b$ & $80.76 \pm 2.16 b$ \\
\hline \multicolumn{2}{|l|}{$\mathrm{MC}$ of rosettes } & $5.24 \pm 1.90 \mathrm{~b}$ & $1.00 \pm 0.00 \mathrm{a}$ & $1.50 \pm 1.22 \mathrm{a}$ & $2.17 \pm 0.41 \mathrm{a}$ & $5.17 \pm 2.86 b$ & $1.66 \pm 0.52 \mathrm{a}$ \\
\hline \multirow[t]{2}{*}{ Length of rosettes } & Green & $3.88 \pm 1.22 \mathrm{a}$ & $3.02 \pm 0.10 \mathrm{a}^{*}$ & $2.67 \pm 0.94 \mathrm{a}$ & $2.88 \pm 0.46 \mathrm{a}$ & $2.08 \pm 0.45 \mathrm{a}$ & $4.35 \pm 1.13 \mathrm{~b}$ \\
\hline & Necrotic & & & $3.69 \pm 0.81 \mathrm{a}$ & $2.55 \pm 0.66 \mathrm{a}$ & $3.04 \pm 0.90 \mathrm{a}$ & $5.03 \pm 0.89 \mathrm{~b}$ \\
\hline \multirow[t]{2}{*}{ Leaf number } & Green & $11.59 \pm 3.39 \mathrm{~b}^{*}$ & $5.34 \pm 1.11 \mathrm{a}^{*}$ & $12.17 \pm 4.12 \mathrm{ab}$ & $9.83 \pm 4.26 \mathrm{a}$ & $23.17 \pm 12.17 b$ & $2.83 \pm 1.94 \mathrm{a}$ \\
\hline & Necrotic & & & $3.17 \pm 2.40 \mathrm{a}$ & $4.83 \pm 1.47 \mathrm{ab}$ & $8.83 \pm 5.11 \mathrm{ab}$ & $10.50 \pm 4.04 \mathrm{~b}$ \\
\hline
\end{tabular}

Values represent mean \pm SD. The means followed by different letters are significantly different at $\mathrm{P}<0.05$

Table 2 The effect type of the induction media on rooting parameters of Pulsatilla turczaninovii micro-rosettes assessed after 6 weeks of different types of culture treatment

\begin{tabular}{llccc}
\hline Medium & Treatment & Rooting efficiency [\%] & $\begin{array}{c}\text { The number } \\
\text { of roots per explant }\end{array}$ & $\begin{array}{c}\text { Average Root } \\
\text { length [cm] }\end{array}$ \\
\hline S3-1 & No PGR & $0 \pm 0 \mathrm{a}$ & $0 \pm 0 \mathrm{a}$ & $0 \pm 0 \mathrm{a}$ \\
S3-2 & IBA $\left(1.0 \mathrm{mg} \mathrm{L}^{-1}\right)$ & $6.66 \pm 3.22 \mathrm{~b}$ & $3.0 \pm 1.0 \mathrm{~b}$ & $0.70 \pm 0.1 \mathrm{~b}$ \\
S3-3 & ACC $\left(1.0 \mathrm{mg} \mathrm{L}^{-1}\right)$ & $19.98 \pm 4.56 \mathrm{c}$ & $1.78 \pm 0.83 \mathrm{~b}$ & $0.48 \pm 0.13 \mathrm{~b}$ \\
S3-4 & IBA $(1.0 \mathrm{mg}$ & $15.54 \pm 8.29 \mathrm{c}$ & $1.83 \pm 0.75 \mathrm{~b}$ & $0.57 \pm 0.08 \mathrm{~b}$ \\
& $\left.\mathrm{~L}^{-1}\right)+\mathrm{ACC}(1.0 \mathrm{mg}$ & & & \\
& $\left.\mathrm{L}^{-1}\right)$ & & & \\
& & & & \\
\hline
\end{tabular}

Values represent mean \pm SD. The means followed by different letters are significantly different at $\mathrm{P}<0.05$ 
Fig. 2 The influence of rooting medium (S3-1, S3-2, S3-3,

S3-4) on the content of total phenolic compounds (TPC) (a), total soluble sugars (TSS) (b) and peroxidase activity (POD) (c) in Pulsatilla turczaninovii micro-rosettes before root induction treatment (day 0) and after 2 and 7 days culture
TPC (mg.eq GA g $\left.{ }^{-1} \mathrm{FW}\right)$

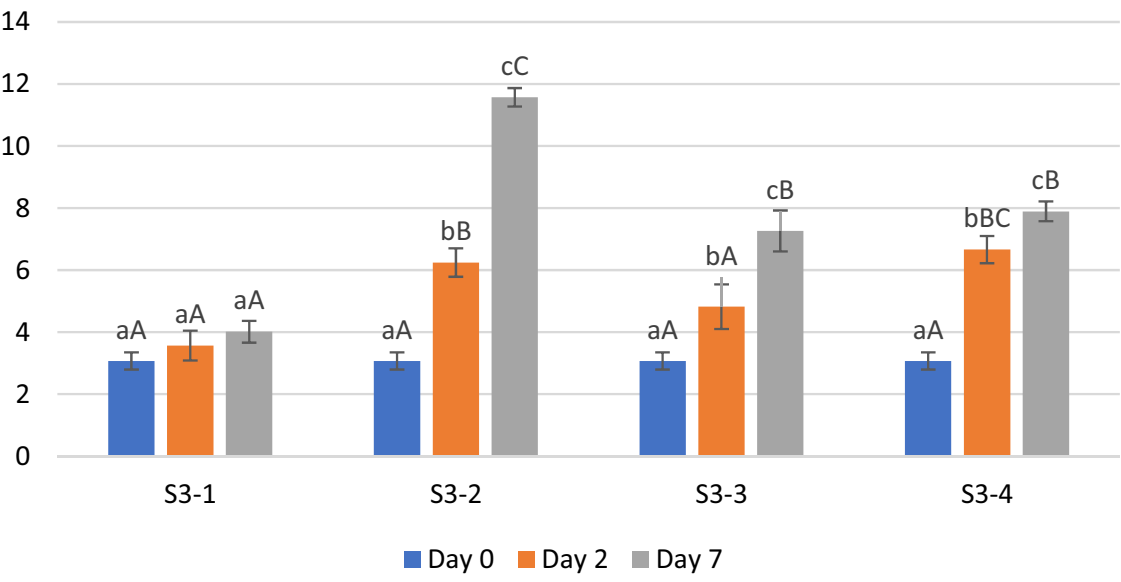

b

TSS (mg.eq glucose $\mathrm{g}^{-1} \mathrm{FW}$ )

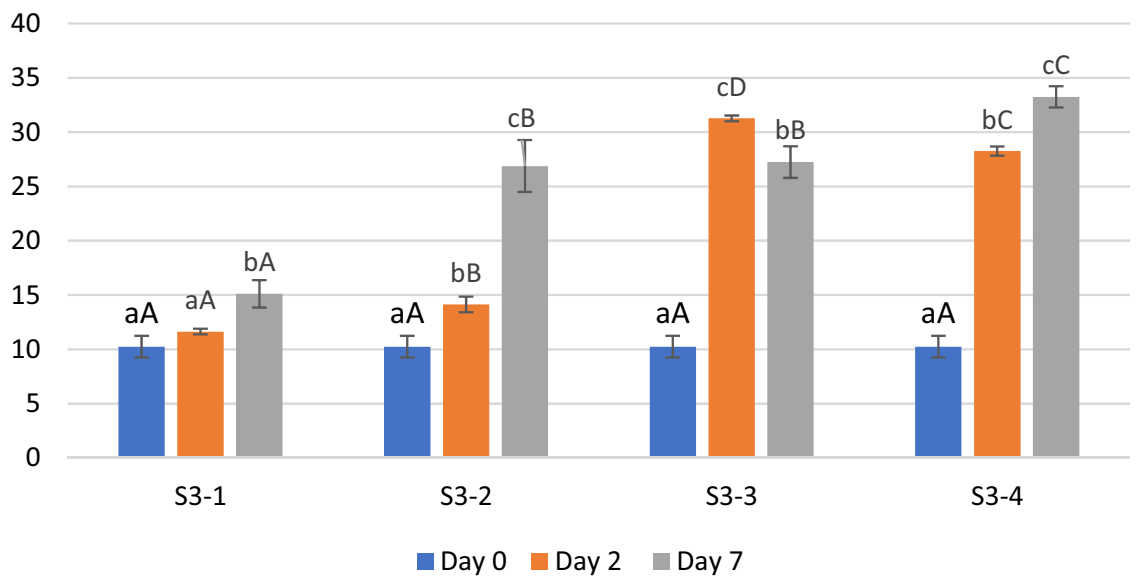

C

POD activity (U/min $\left./ 1 \mathrm{~g}^{-1} \mathrm{FW}\right)$

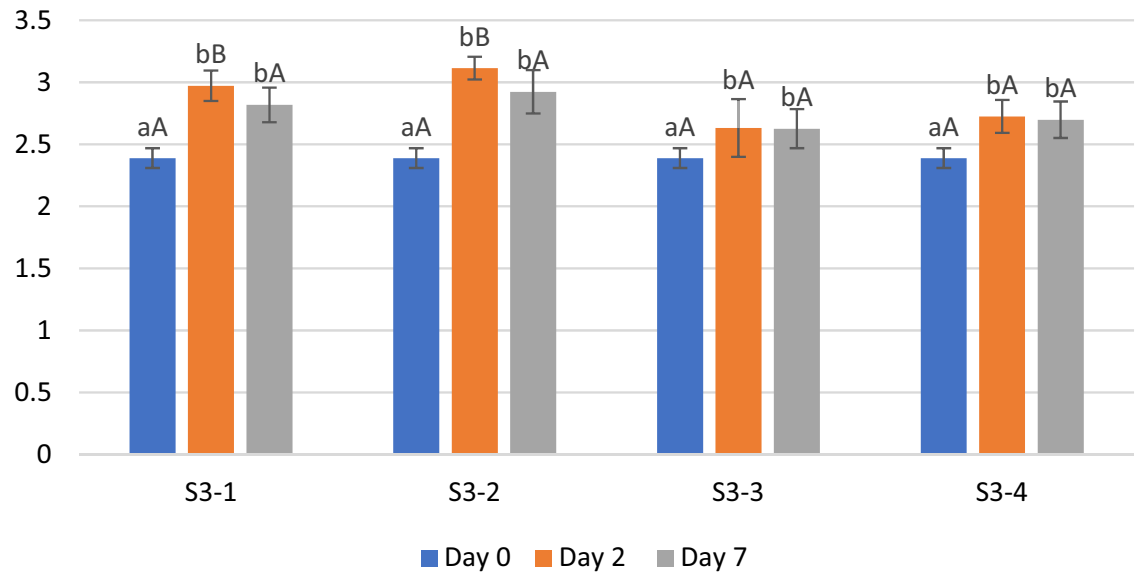


not changed throughout the entire induction phase that lasted 7 days. TPC increased significantly on the second day on media S3-2, S3-3 and S3-4, with the highest concentration determined for medium S3-2. On the seventh day of induction phase, further increase of TPC occurred in all phytohormone-enriched media. Again the highest TPC content was the highest on S3-2 medium, where it increased threefold in comparison with S3-1 medium reaching $11.17 \mathrm{mg} \mathrm{g}^{-1} \mathrm{FW}$. On media S3-3 and S3-4 micro-rosettes accumulated similar amounts of TPC, amounting to $7.26 \mathrm{mg} \mathrm{g}^{-1} \mathrm{FW}-\mathrm{S} 3-3$ and $7.89 \mathrm{mg} \mathrm{g}^{-1} \mathrm{FW}-\mathrm{S} 3-4$ (Fig. 2A).

Total content of soluble sugars (TSS) significantly increased between the beginning (day 0 ) and the second day of rooting induction phase in the media containing phytohormones: S3-2, S3-3 and S3-4. In the same period on medium S3-1 TSS content remained unchanged (Fig. 2B). TSS level rapidly rose on media S3-3 and S3-4, however the highest concentration on medium S3-3 was determined on the second day, while on medium S3-4 on the seventh day of rooting induction. On hormone-free S3-1 medium TSS increased slightly, but significantly, on the seventh day.

Peroxidase activity (POD) increased significantly on second day of cultivation on rooting medium, irrespectively of its composition (Fig. 2C). Enzyme activity on the seventh day on media S3-3 and S3-4 remained as high as on the second day. In turn, on media S3-1 and S3-2 POD activity was slightly lower at the end of rooting induction phase than on its second day. However, it was still higher than at the beginning of rooting experiment. Considering the changes observed on the second day, POD activity was higher in microrosettes from media S3-1 and S3-2 than on media S3-3 and S3-4. On the seventh day enzyme activity was the same, irrespectively of medium type (Fig. 2C).

Significant correlations were found between some rooting parameters and the levels of biomarkers (Table 3). Rooting efficiency was positively correlated with TSS content, and negatively with POD activity, determined in both terms of root induction phase. Correlation coefficients were particularly strong when these compounds were analyzed on the second day $(R=0.974$ and $R=-0.834$ for TSS and POD, respectively) in comparison with the seventh day (Table 3). TSS content on the 7th day was positively correlated also with root length $(\mathrm{R}=0.863)$ and root number $(0.730)$. These two rooting parameters were positively correlated with TPC contents determined in both terms (Table 3), as well as with each other $(R=0.975)$. In case of biomarkers we noted that on the second day TSS content was negatively correlated with POD activity.

\section{Pulsatilla turczaninovii cultivation}

Ex situ germination of $P$. turczaninovii seeds taken from natural site (Suppl. Fig. 1) was evaluated. This sub-experiment was performed to obtain reference plant material for plants produced as a result of in vitro culture. The average percent of seed germination after 4 weeks was $49.7 \%$. In the first year, the obtained plants differed in the number of true leaves produced. Two to six leaves developed during 16 weeks. After 16 weeks, the seedlings obtained in the seed boxes, were transferred into pots. The plants were divided into two groups, of six plats each, one group hibernated in the ground, and the other was kept in an unheated greenhouse. The plants left in the greenhouses developed longer leaves. In the following season, $83.3 \%$ of plants continued to grow, and $16.7 \%$ of them developed 1-2 flowers. In the third season, all reference plants entered the generative phase. Another wintering turned out to be troublesome, as plants with the largest (constituting 3.6\%) biomass were partially rotting. After acclimatization to ex vitro conditions $88.6 \%$ of rooted micro-plants were planted out in the rock garden, The
Table 3 Correlation matrix of biochemical markers: the content of total phenolics (TPC), total soluble sugars (TSS) and peroxidase activity (POD), determined after 2 and 7 days of rooting induction, and rooting parameters ( $\mathrm{R} \%$ - rooting efficiency, R L root length, Root no./ex number of roots per rooted explant)

\begin{tabular}{|c|c|c|c|c|c|c|}
\hline & TPC & TSS & POD & $\mathrm{R} \%$ & R L & Root no./ex \\
\hline & \multicolumn{6}{|c|}{2 days of rooting induction } \\
\hline ТРC & \multicolumn{6}{|c|}{1.000} \\
\hline TSS & 0.371 & 1.000 & & & & \\
\hline POD & -0.053 & -0.932 & 1.000 & & & \\
\hline $\mathrm{R} \%$ & 0.461 & 0.974 & -0.834 & 1.000 & & \\
\hline R L & 0.897 & 0.401 & -0.049 & 0.568 & 1.000 & \\
\hline \multirow[t]{2}{*}{ Root no./ex } & 0.813 & 0.241 & 0.126 & 0.430 & 0.975 & 1.000 \\
\hline & \multicolumn{6}{|c|}{7 days of rooting induction } \\
\hline ТРC & 1.000 & & & & & \\
\hline TSS & 0.630 & 1.000 & & & & \\
\hline POD & 0.379 & -0.365 & 1.000 & & & \\
\hline $\mathrm{R} \%$ & 0.252 & 0.782 & -0.780 & 1.000 & & \\
\hline R L & 0.930 & 0.863 & 0.031 & 0.568 & 1.000 & \\
\hline Root no./ex & 0.982 & 0.730 & 0.198 & 0.430 & 0.975 & 1.000 \\
\hline
\end{tabular}


results collected during subsequent three seasons of their cultivation are presented in Table 4, while Fig. 3 presents structural elements of the mature, flowering plant. Similarly to the reference plants, plants from micropropagation were divided into the two groups with a similar effect. Plants kept under covers were developing much more dynamically in the next growing season and these plants were further assessed. The plants did not differ in morphological features from the material grown as reference material. In the third year of cultivation, plants that had undergone acclimatization in the greenhouse, produced from a few to a dozen flowers and numerous shoots, creating large clumps of leaves.

\section{Discussion}

In the presented study, we dealt with difficult plant material, and the starting material for the experimental work was taken from a local population. Most Pulsatilla species are confined to temperate areas of the Northern hemisphere, and prefer dry grassland habitats, as for example European lowland populations of $P$. pratensis (Bochenková et al. 2012, 2015) or P. grandis (Bochenková et al. 2017). Whereas, Asiatic species such as $P$. turczaninovii, $P$. flavescens or $P$. bungeana can be found in North-Mongolian forest-steppe (Dulamsuren et al. 2005a, b; Gantuya et al. 2019; Gunin et al. 2020), and Altai-Sayan mountain steppes (Namzalov et al. 2018; Shadgar and Yadamsuren 2017). The habitat of P. turczaninovii were also ascertained in the alpine meadows in the mountainous area over $1000 \mathrm{~m}$ above sea level (Ermakow et al. 2014), and in lake Baikal's region. P. turczaninovii is one of the important species of flora of the Baikalian Region, and this species should be preserved as a valuable resource for future generations. Improving propagation, cultivation and seed storage conditions gives an opportunity to maintain plant biodiversity (Danova et al. 2009; Grigoriadou et al. 2011, 2019; Abeli et al. 2020). Previously, tissue culture of P. patens was initiated by Priede and Kḷavinina (2011) from seeds collected from naturally grown population and in our study the same methodological approach was chosen for $P$. turczninovii. In this study initial material for in vitro culture was obtained from the sown achenes. The germination percentage in vitro reached nearly 55, which is an acceptable value, considering prolonged storage of the seeds and surface disinfection procedures. Kozłowski (1959), based on the research of $P$. pratensis, proved that with the storage of fruit, seeds lose their value, and germination decreases by about $30 \%$. While in the case of $P$. patens the percentage of seed germination of freshly harvested fruit varied from 80 to $98 \%$, and after a few months of storage it dropped to $60 \%$ (Priede and Kḷavinina 2011). In our experiment, the incised achenes were sown some months after the harvest date, which may be the reason for their relatively low emergence. The results

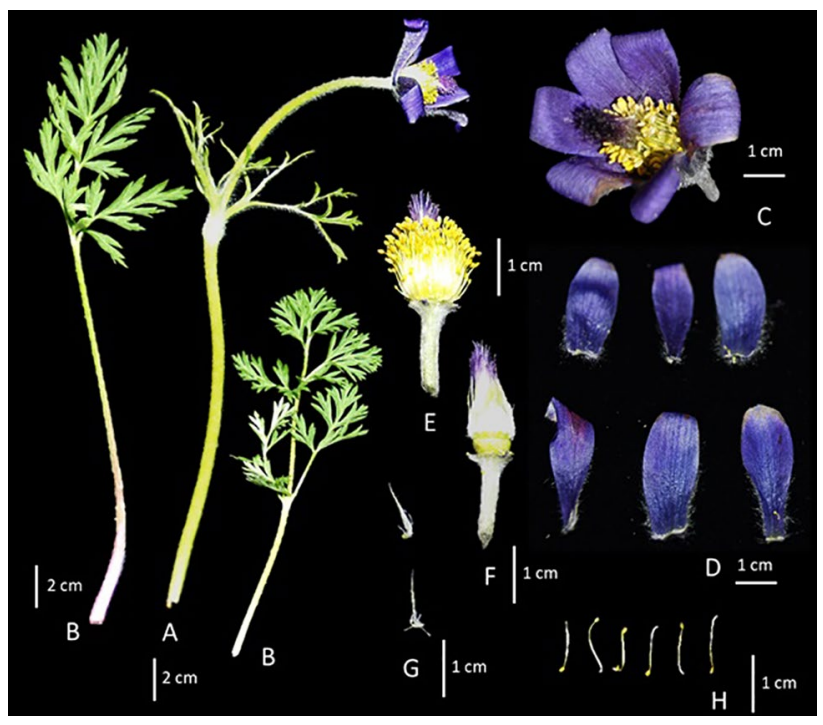

Fig. 3 Morphology of Pulsatilla turczaninovii: A Blooming shoot, $B$ leaf, $C$ flower, $\underline{D}$ perianth, $E$ receptacle with pistils and stamens, $F$ receptacle with pistils, $G$ individual pistil, $H$ single stamens

obtained for studied $P$. turczaninovii population correspond to the percentage of P. patens seeds germinating after several months of storage by Priede and Kḷavina (2011). Yuan et al. (2019) conducted extensive research on the germination of $P$. turczaninovii and breaking of seed dormancy. Visually full seeds upon harvest germinated in $52.6 \%$, but seeds that were dry stored for 44 weeks had lower germination ratefrom 26.3 to $29.7 \%$. In our study germination percentage of stored seeds was similar to that recorded for seeds sown directly after harvest by Yuan et al. (2019).

Here we describe a complete protocol of micro-reproduction of Pulsatilla turczaninovii under in vitro culture conditions. Until now, some research has been conducted on the cultures of few Pulsatilla species (Jin et al. 2007; Danova et al. 2009; Lin et al. 2011; Priede and Kḷaviņa 2011) but there were no available literature data on in vitro cultures of $P$. turczaninovii. It is therefore the first study to assess the organogenic potential of this species in tissue culture. While considering tissue culture-based researches of Asian species, it is worth mentioning studies by Jin et al. (2007) and Lin et al (2011) regarding Pulsatilla koreana, known for synthesis of valuable bioactive compounds. Lin et al. (2011) regenerated P. koreana, via organogenesis and somatic embryogenesis (SE). In $P$. turczninovii a protocol for obtaining rooted plants through organogenesis was achieved in our research, but conditions for SE still need to be elaborated.

The success of culture mostly depends on application of two crucial growth regulators: auxins and cytokinins. Considering auxins, it was found that medium supplementation with IAA gave a satisfactory growth response as manifested by an increased number of shoots and a high rate of rooting 


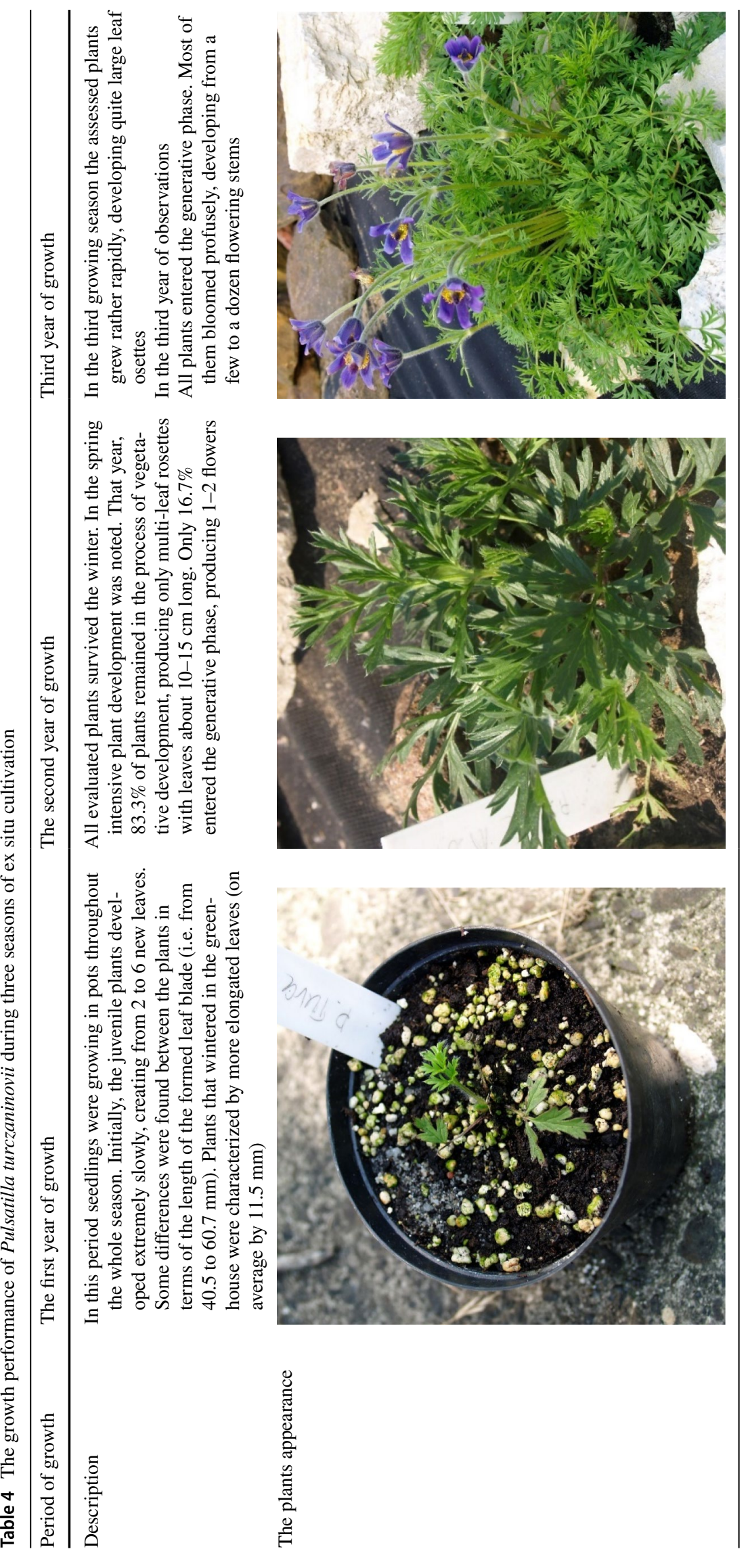


(Victorio et al. 2012). For P. vulgaris and $P$. grandis, IAA was applied in concentrations ranging from 0.1 to $0.5 \mathrm{mg}$ $\mathrm{L}^{-1}$, and was usually combined with cytokinin benzyladenine (BA) (Šaulienè and Brinkytė 2009). Priede and Kḷaviņa (2011) tested the response to BA and other cytokinins. Benzyladenine and topolin at concentrations of 0.25 and $0.5 \mathrm{mg}$ $\mathrm{L}^{-1}$ resulted in threefold multiplication rate, while $5 \mathrm{mg} \mathrm{L}^{-1}$ kinetin caused twofold increase of shoot number. In turn, shoot propagation of $P$. koreana was achieved using $0.05 \mathrm{mg}$ $\mathrm{L}^{-1}$ IAA along with variable concentrations of zeatin and BA. The best effects were obtained for $1.5 \mathrm{mg} \mathrm{L}^{-1}$ zeatin and $1.0 \mathrm{mg} \mathrm{L}^{-1} \mathrm{BA}$, where propagation coefficient reached 21.3 and 7.1, respectively (Lin et al. 2011). Average shoot length for this species was proved higher than in P. turczaninovii. On media with $2.5 \mathrm{mg} \mathrm{L}^{-1} 2 \mathrm{iP}$ and $1 \mathrm{mg} \mathrm{L}^{-1}$ IAA, we have obtained a multiplication ratio exceeding 5.0. This indicates that cytokinin $2 \mathrm{iP}$ may induce organogenic potential in Pulsatilla species more effectively than topolin and kinetin. Apart from high multiplication coefficient, medium suitability for $P$. turczaninovii cultivation was also ascertained by achieving higher fresh weight and the highest number of green leaves.

The formation of adventitious roots on microcuttings is a critical step to obtain plants ready to be acclimatized to $e x$ vitro conditions. We proved that during rooting of $P$. turczaninovii micro-rosettes the rooting efficiency was higher on media with the $1.0 \mathrm{mg} \mathrm{L}^{-1}$ of ethylene precursor ACC in comparison with medium supplemented with $1.0 \mathrm{mg}$ $\mathrm{L}^{-1}$ of indole-3-butyric acid (IBA), and rooting percentage amounted to 15.5-19.98. Arigita et al. (2003) also found that supplementation of rooting medium with low ACC levels facilitates adventitious root induction of Actinidia. Rooting was also enhanced by ACC addition in the cultures of apple (Ma et al. 1998) and peach (Park et al. 2017). It was attributed to interactions between ethylene and auxin levels in the regulation of adventitious rooting (Velocia et al. 2016; Park et al. 2017). Altamura research group working with $A$. thaliana (Velocia et al. 2016; Fattorini et al. 2018) found that $\mathrm{ACC}$ at $0.1 \mu \mathrm{M}$ concentration promotes root formation when combined with IBA $(10 \mu \mathrm{M})$, but reduced it when used alone. In our study, however, both variants were beneficial for induction of rooting. Šedivá (2012) indicated that incision in the base improved rooting of $P$. vernalis. However, achieved rooting efficiency in culture, reaching 15-20\%, would not be satisfactory for production of $P$. turczaninovii.

Rooting difficulties limit the reproductive rate of the species, and also constitute a serious obstacle to its commercial propagation. In order to improve this stage of plant development, it is necessary to provide insight into the physiology of rooting difficult-to-root species (Wiszniewska et al. 2016). Changes in phenolic and carbohydrate accumulation as well as in the activity of peroxidase were associated with rooting ability, and root formation at the earliest stages of rhizogenesis (de Klerk et al. 1999; Günes 2000; Denaxa et al. 2020). Monitoring their fluctuations may allow for the selection of the most optimal time for transferring shoots/ rosettes to elongation medium This time would be related to the requirement of cultured rosettes for auxin (de Klerk et al. 1999; Wiszniewska et al. 2016). We observed that in $P$. turczaninovii rooting parameters improved when accumulation of soluble sugars was enhanced, similar to that of carnation cuttings (Agulló-Antónet al. 2011). The content of soluble sugars on the second day of the root induction phase was positively correlated with rooting efficiency, and on the seventh day with all the examined rooting characteristics. Involvement of carbohydrates, particularly soluble sugars, in the rooting process is related to their role as a carbon and energy source (Megre et al. 2011; Otiende et al. 2017). In this respect, we consider TSS to be the best biomarker in studied species, and factors stimulating TSS synthesis could potentially increase rooting ability. Rooting was also promoted when moderate level of phenolic compounds was maintained, since at low and high TPC concentrations root formation was strongly limited. In P. turczaninovii this parameter was positively correlated with root length and number. It may reflect influence of TPC on formation of root meristematic centers (Druege et al. 2000). Surprisingly, our study showed that POD activity was negatively correlated with rooting efficiency in $P$. turczaninovii culture, and it did not correspond with root length and number. However, its usefulness as a rooting biomarker was mainly assessed in studies on woody plants (Günes 2000; Merge et al. 2011). Scheduled analyses of the POD fractions related to the cell protoplast and cell-wall may facilitate the verification of the role of POD in P. turczaninovii adventitious rooting. It is postulated that the highest POD activity occurs at the end of the root initiation phase, and prolonged exposure to exogenous auxin may inhibit further root development (Gaspar et al. 1992; Li et al. 2009). In our experiment, the observed decline in POD activity at the seventh day on media S3-1 and S3-2 may suggest that the optimal transfer time to the hormone-free medium had to be done a little earlier. Application of ACC could delay the initiation phase, and therefore the root formation was not suppressed. As noted above, the higher rootability occurred in media containing an ethylene precursor, alone or in a combination with auxin. It may be attributed to ethylene potential to control distribution of root initiation regions (Rasmussen et al. 2017). To our best knowledge these are first data related to biochemical background of adventitious rooting in Pulsatilla species. 


\section{Conclusions}

We herewith obtained Pulsatilla turczaninovii plant tissue bank under in vitro conditions, which is sine qua non condition to create ex situ collection. Propagation protocol was elaborated using a modified MS medium enriched with $2 \mathrm{iP}$ and IAA. It was ascertained that the addition of $1.0 \mathrm{mg}$ $\mathrm{L}^{-1} \mathrm{ACC}$ and $1.0 \mathrm{mg} \mathrm{L}^{-1} \mathrm{IBA}$ improves rooting of regenerated micro-rosettes. Our study revealed also that accumulation of soluble sugars has significant impact on rhizogenesis efficiency, as well as on some characteristics of regenerated roots, providing an insight into biochemical control of adventitious rooting in $P$. turczaninovii. We proved that successful cultivation of $P$. turczaninovii can be carried out in the climatic conditions of Poland. However, it is necessary to properly select the site and prepare the substrate for the optimal growth of the regenerated plants. Developed micropropagation protocol may be used for obtaining of plant material for breeding schemes or plain horticultural production.

Supplementary Information The online version contains supplementary material available at https://doi.org/10.1007/s11240-021-02140-0.

Acknowledgements We would like express our gratitude to His Magnificence Rector of University of Agriculture in Krakow for co-financing the trip of some participants of Interdepartmental Phytogeography Student's Scientific Circle with their tutors from research and teaching staff to the M. K. Ammosov North-Eastern Federal University and the Botanic Garden of the Irkutsk State University, Russia and their scientific expedition to the area of Lake Baikal, as well as the possibility of visiting in Baikal Museum ITS SB RAS. The statutory activity of Department of Botany, Physiology and Plant Protection, University of Agriculture in Kraków as laboratory research, field experiments and publication of results were financed by the Ministry of Science and Higher Education of the Republic of Poland.

Author contributions Conceptualization: EH-F, AW, DK; Methodology: E.H-F, AW, DK, AK; Seed Germination and Plant Culture: DK, EM, EH-F; Biochemical analyses: AK; Statistical analyses AK, AW; Writing-Original Draft Preparation: EH-F, DK; AW; WritingReview \& Editing: EH-F; AW; Supervision EH-F; Funding Acquisition: EH-F. This research was supported by Ministry of Science and Higher Education of the Republic of Poland in the form of subsidy No. 2016-2020-0012-D011.

Open Access This article is licensed under a Creative Commons Attribution 4.0 International License, which permits use, sharing, adaptation, distribution and reproduction in any medium or format, as long as you give appropriate credit to the original author(s) and the source, provide a link to the Creative Commons licence, and indicate if changes were made. The images or other third party material in this article are included in the article's Creative Commons licence, unless indicated otherwise in a credit line to the material. If material is not included in the article's Creative Commons licence and your intended use is not permitted by statutory regulation or exceeds the permitted use, you will need to obtain permission directly from the copyright holder. To view a copy of this licence, visit http://creativecommons.org/licenses/by/4.0/.

\section{References}

Abeli T, Dalrymple S, Godefroid S, Mondoni A, Müller JV, Rossi G, Orsenigo S (2020) Ex situ collections and their potential for the restoration of extinct plants. Conserv Biol 34(2):303-313. https:// doi.org/10.1111/cobi.13391

Agulló-Antón MÁ, Sánchez-Bravo J, Acosta M, Druege U (2011) Auxins or sugars: what makes the difference in the adventitious rooting of stored carnation cuttings? J Plant Growth Reg 30:100-113. https://doi.org/10.1017/s00344-010-9174-8

Arigita L, Sánchez Tamés R, González A (2003) 1-Methylcyclopropene and ethylene as regulators of in vitro organogenesis in kiwi explants. Plant Growth Reg 40:59-64. https://doi.org/10.1023/A: 102307031422

Blainski A, Lopes GC, De Mello JCP (2013) Application and analysis of the Folin Ciocalteu method for the determination of the total phenolic content from Limonium brasilense L. Molecules 18:6852-6865. https://doi.org/10.3390/molecules18066852

Bochenková M, Hejcman M, Karlīk P (2012) Effect of plant community on recruitment of Pulsatilla pratensis in dry grassland. Sci Agric Bohem 4:217-133. https://doi.org/10.7160/sab.2012. 430402

Bochenková M, Karlīk P, Hejcman M (2015) Effect of nitrogen, appendage removal, locality and year on seed germination of the endangered dry grassland species Pulsatilla pratensis (L.) Mill. Prop Ornam Plants 15(4):154-162

Bochenková M, Karlīk P, Hejcman M, Jiras P (2017) Does seed modification and nitrogen addition affect seed germination of Pulsatilla grandis? Sci Agric Bohem 48(4):106-223. https://doi.org/ 10.1515/sab-2017-0029

Danova K, Bertoli A, Pistelli L, Dimitrov D, Pistelli L (2009) In vitro culture of Balkan endemic and rare Pulsatilla species for conservational purposes and secondary metabolites production. Bot Ser 33(2): $157-162$

De Klerk G-J, van der Krieken W, De Jong JC (1999) The formation of adventitious roots: new concepts, new possibilities. In Vitro Cell Dev Biol Plant 35:189-199. https://doi.org/10.1007/ s11627-999-0076-z

Denaxa NK, Vemmos SN, Roussos PA (2012) The role of endogenous carbohydrates and seasonal variation in rooting ability of cuttings of an easy and a hard to root olive cultivars (Olea europaea L.). Sci Hort 143:19-28. https://doi.org/10.1016/j.scienta.2012.05.026

Denaxa NK, Roussos PA, Vemmos SN (2020) Assigning a role to the endogenous phenolic compounds on adventitious root formation of olive stem cuttings. J Plant Growth Reg 39:411-421. https:// doi.org/10.1007/s030344-019-09991-0

Di Musciano M, Carranza ML, Frate L, Di Cecco V, Di Martino L, Fratolli R, Stanisci A (2018) Distribution of plant species and dispersal traits along environmental gradients in Central Mediterranean Summits. Diversity 10:58. https://doi.org/10.3390/d10030058

Druege U, Zerche S, Kadner R, Ernst M (2000) Relation between nitrogen status, carbohydrate distribution and subsequent rooting of chrysanthemum cuttings as affected by pre-harvest nitrogen supply and cold-storage. Ann Bot 85(5):687-701. https://doi.org/10. 1006/anbo.2000.1132

Dulamsuren Ch, Hauck M, Mühlenberg M (2005a) Ground vegetation in the Mongolian taiga forest-steppe ecotone does not evidence for the human origin of grasslands. Appl Veg Sci 8:149-154

Dulamsuren Ch, Welk E, Jäger EJ, Hauck M (2005b) Range-habitat relationships of vascular plant species at the taiga-forest steppe borderline in the western Khentey Mountains, northern Mongolia. Flora 200:375-379. https://doi.org/10.1016/j.flora.2005.02.002

Ermakow N, Larionov A, Polyakova M, Pestunov I, Didukh Y (2014) Diversity and spatial structure of cryophytic steppes of the 
Minusinskaya intermountain basin in Southern Siberia (Russia). Tuxenia 34:431

Fattorini L, Hause B, Gutierrez L, Veloccia A, Della Rovere F, Piacentini D, Falasca G, Altamura MM (2018) Jasmonate promotes auxin-induced adventitious rooting in dark-grown Arabidopsis thaliana seedlings and thin stem layers by cross-talk with ethylene signaling and modulation of xylogenesis. BMC Plant Biol 18:182. https://doi.org/10.1186/s12870-018-1392-4

Gantuya B, Avar Á, Babai D, Molnár ZS (2019) “A herder's duty to think": landscape partitioning and folk habitats of Mongolian herders in a mountain forest steppe (Khuvusgul-Murun region). J Ethnobiol Ethnomed 15:54. https://doi.org/10.1186/ s13002-019-0328-x

Gaspar T, Kevers C, Hausman J, Jy B, Ripetti V (1992) Practical uses of peroxidase activity as a predictive marker of rooting performance of micropropagated shoots. Agro EDP Sci 12(10):757-765

Grigoriadou K, Krigas N, Maloupa E (2011) GIS-facilitated in vitro propagation and ex situ conservation of Achilea occulta. Plant Cell Tiss Organ Cult 107:531-540. https://doi.org/10.1007/ s11240-011-0004-x

Grigoriadou K, Krigas N, Sarropolou V, Papanastasi K, Tsoktourdis G, Maloupa E (2019) In vitro of medicinal and aromatic plants: the case of selected Greek species with conservation priority. In Vitro Cell Dev Biol Plant 55:635-646. https://doi.org/10.1007/s1162 7/-019-10014-6

Günes T (2000) Peroxidase and IAA-oxidase activities during rooting in cuttings of three poplar species. Turk J Bot 24:97-101

Gunin PD, Bazha SN, Miklyaeva IM, Karimova TY, Petukhow IA, Andreev AV, Bogdanov EA, Tsyrempilov EG (2020) Practice of geobotanical indication of forest growth conditions in the steppe and wooded steppe ecotone in Central Mongolia. J Ecol Eng 21(2):10-21. https://doi.org/10.12911/22998993/116340

Hanus-Fajerska E, Ciarkowska K, Muszynska E (2019) Long-term field study on stabilization of contaminated wastes by growing clonally reproduced Silene vulgaris calamine ecotype. Plant Soil 439:431-445. https://doi.org/10.1007/s11104-019-04043-8

Hao DC, Xiao PG, Ma HY, Peng Y, He CN (2015) Mining chemodiversity from biodiversity: pharmacophylogeny of medicinal plants of Ranunculaceae. Chin J Nat Med 13(7):507-520

Jin JS, Hun JJ, Soo YE, Eui CY (2007) Plant regeneration and adventitious root segments of Pulsatilla koreana Nakai. J Plant Biotech 34(2):153-159. https://doi.org/10.5010/JPB.2007.34.2.153

Kozłowski J (1959) Attempts to grow pasque-flower as a medicinal plant (In Polish). Wiad Bot III(2):121-123

Łaska G, Sienkiewicz A (2019) Antifungal activity of rhizome extracts of Pulsatilla vulgaris against Candida glabrata. Eur J Biol Res 9(2):93-103. https://doi.org/10.5281/zendo.3228890

Łaska G, Sienkiewicz A, Stocki M, Zjawiony JK, Shrama V, Bajguz A, Piotrowska-Niczyporuk A, Jacob M, Khan S (2019) Phytochemical screening of Pulsatilla species and investigation of their biological activities. Acta Soc Bot Pol 88(1):3613. https://doi.org/ 10.5586/asbp. 3613

Li SW, Xue L, Xu S, Feng H, An L (2009) Mediators, genes and signaling in adventitious rooting. Bot Rev 75(2):230-247

Lin GZ, Zhao XM, Hong SK, Lian YJ (2011) Somatic embryogenesis and shoot organogenesis in the medicinal plant Pulsatilla koreana Nakai. Plant Cell Tiss Organ Cult 106:93-103. https://doi.org/10. 1007/s00240-010-9897-z

Lloyd G, Mc Cown B (1980) Commercially-feasible micropropagation of mountain laurel, Kalmia latifolia, by use of shoot tip culture. Comb Proc Int Plant Prop Sic 30:21-427

Ma JH, Yao JL, Cohen D, Morris B (1998) Ethylene inhibitors enhance in vitro root formation from apple cultures. Plant Cell Rep 17:211-214

Megre D, Dokane K, Kondratovics U (2011) Can changes in starch content and peroxidase activity be used as rooting phase markers for rhododendron leaf bud cuttings? Act Biol Crac Ser Bot 53(1):74-79. https://doi.org/10.2478/v10182-011-0010-7

Mlinarec J, Franjević D, Bočkor L, Besendorfer V (2016) Diverse evolutionary pathways shaped $5 \mathrm{~s}$ rDNA of species of tribe Anemonae (Ranunculaceae) and reveal phylogenetic signal. Bot J Linn Soc 182:80-99. https://doi.org/10.1111/boj.12425

Murashige T, Skoog F (1962) A revised medium for rapid growth and bioassays with tobacco tissue cultures. Physiol Plant 15:473-497. https://doi.org/10.1111/j.1399-3054-1962.tb08052.x

Muszyńska E, Hanus-Fajerska E, Koźmińska A (2018) Differential tolerance to lead and cadmium in micropropagated Gypsophila fastigiata ecotype. Water Air Soil Pollut 229:42. https://doi.org/ 10.1007/s11270-018-3702-8

Namzalov BBT, Zhigzhitzhapova SV, Taisaev TT, Radnaeva LD, Banaeva SC, Namzalov MBT (2018) On the relic phenomena and influence of volcanic rocks on vegetation of mountain steppes in Southern Siberia. Arid Ecosyst 8(2):111-121

Otiende MA, Nyabundi JO, Ngamau K, Opala P (2017) Effects of cutting position of rose rootstock cultivars on rooting and its relationship with mineral nutrient content and endogenous carbohydrates. Sci Hort 225:204-212

Park SH, Elhiti M, Wang H, Xu A, Brown D (2017) Adventitious root formation of in vitro peach shoots is regulated by auxin and ethylene. Sci Hort 226:250-260. https://doi.org/10.1016/j.scienta. 2017.08.05

Philips GC, Garda M (2019) Plant tissue culture media and practices: an overview. Vitro Cell Dev Biol Plant 55:242-257. https://doi. org/10.1007/s11627-019-09983-5

Powel Gaines T (1973) Automated determination of reducing sugars, total sugars, and starch in plant tissue from one weighted sample. J Ass Anal Chem 56(6):1419-1424. https://doi.org/10.1093/joac/ 56.6.1419

Popovicheva O, Molozhnikova E, Nanasov S, Potemkin V, Penner I, Klemasheva M, Marinaite I, Golobokova L, Vratolis S, Eleftheriadis K, Khodzher T (2021) Industrial and wildfire aerosol pollution over heritage Lake Baikal. J Environ Sci 107:49-64. https:// doi.org/10.1016/j.jes.2021.01.011

Priede G, Klavina D (2011) In vitro cultivation and root initiation of the endangered plant Pulsatilla patens. Environ Exp Bot 9:71-74

Putter J (1974) Peroxidases. In: Bergmeyer HV (ed) Methods of enzymatic analysis II. Academic Press, New York, pp 685-690

Rasmussen A, Hu Y, Depaepe T, Vandenbussche F, Boyer FD, Van Der Straeten D, Geelen D (2017) Ethylene controls adventitious root initiation sites in Arabidopsis hypocotyls independently of strigolactones. J Plant Growth Reg 36(4):897-911

Šaulienè I, Brinkytė E (2009) The impact of phytohormones on pasqueflower (Pulsatilla) regeneration in vitro. Act Biol Univ Daugavpiliensis. 9(2):249-254

Šedivá J (2012) In vitro root formation in Pulsatilla vernalis (L.) Mill. Prop Ornam Plants 12:96-101

Shadgar D, Yadamsuren O (2017) Plant species and vegetation cover of Kherlen Toono Mountain, Mongolia. J Asia-Pac Biodiv. https:// doi.org/10.1016/j.apb.2016.06.005

Sramkó G, Laczkó L, Volkova PA, Bateman RM, Mlinarec J (2019) Evolutionary history of the Pasque-flowers (Pulsatilla, Ranunculaceae): molecular, phylogenetics, systematics, and rDNA evolution. Mol Phyl Evol 135:45-61. https://doi.org/10.1016/j.ympev. 2019.02.015

Velocia A, Fattorini L, Della Rovere F, Sofo A, D’Angeli D, Betti C, Falasca G, Altamura MM (2016) Ethylene and auxin interaction in the control of adventitious rooting in Arabidopsis thaliana. $\mathrm{J}$ Exp Bot 67(22):6445-6458. https://doi.org/10.1093/jxb/erw415

Victório CP, Lage C, Lage S, Sato A (2012) Tissue culture techniques in the proliferation of shoots and roots of Calendula officinalis. Rev Ciência Agron 43(3):539-545 
Weryszko-Chmielewska E, Sulborska A, Żuraw B, Chyzewska R, Sawdis T (2017) Ecological aspects of the floral structure and flowering of Pulsatilla species. Acta Agrobot 70(3):1715. https:// doi.org/10.5586/aa.1715

Wiszniewska A, Nowak B, Kołton A, Sitek E, Grabski K, Dziurka M, Tukaj Z (2016) Rooting response of Prunus domestica L. microshoots in the presence of phytoactive medium supplements. Plant Cell Tiss Organ Cult 125(1):163-176

Xu XT, Jin X, Liao WB, Dawuda MM, Li XP, Wang M, Niu LJ, Zhu YC (2017) Nitric oxide is involved in ethylene-induced adventitious root development in cucumber (Cucumis sativus L.) explants. Sci Hort 215:65-71. https://doi.org/10.1016/j.scienta. 2016.12.006

Xu L, Nie Y, Chen B, Xin X, Yang G, Xu D, Ye L (2020) Effects of fence enclosure on vegetation community characteristics and productivity of a degraded temperate meadow steppe in Northern China. Appl Sci 10:2952. https://doi.org/10.3390/app10082952
Yuan T, Wei Q, Bauchan G (2019) Germination of Pulsatilla seeds as influenced by seed morphology, moisture and gibberellin $\left(\mathrm{GA}_{3}\right)$ treatment, and detection of nickel in seeds. HortSci 54(11):20152023. https://doi.org/10.21273/HORTSCI14056-19

Zainelabdeen YM, Yan R, Xin X, Yan Y, Ahmed AI, Hou L, Zhang Y (2020) The impact of grazing on the grass composition in temperate grassland. Agronomy 10:1230. https://doi.org/10.3390/agron omy 10091230

Publisher's Note Springer Nature remains neutral with regard to jurisdictional claims in published maps and institutional affiliations. 